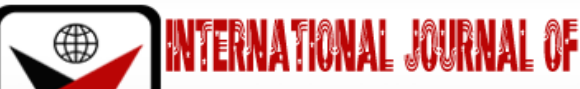

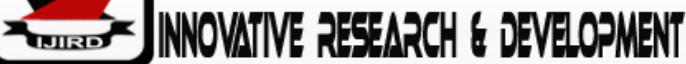

ISSN $2278-0211$ (Online)

\section{Relationship between Selected Sex-related Activities and Academic Performance of Secondary School Students in Kakamega Central Sub-county, Kenya}

\begin{tabular}{c}
\hline Dr. Christopher Omusula Bwamoni \\
Senior Lecturer, Department of Education Planning \& Management, \\
Masinde Muliro University of Science and technology, Kenya \\
Lavera Leah Namachi \\
Lecturer, Department of Education Foundations, Mount Kenya University, Kenya \\
\hline
\end{tabular}

\section{Abstract:}

Educationists have observed that candidates' summative scores in their exams correlates strongly with their continuousassessment's tests in their former classes. They allege that although early sexual debut may not be a direct course of poor academic performance,higher educational aspiration is associated with postponement of sexuallyrelated activities. This study sought to determine the degree to which exposure to Internet Pornography affected the academic performance of students in Kakamega Central Sub County.The study employed Psychosocial Theory of Personality development to support its findings.It adopted an ex-post facto research design to collect both quantitative and the qualitative data.A total of 4073 respondents consisting of 28 principals, 28 Heads of Department Guidance and Counseling and 4017 students participated. It used purposive sampling to select 28 principals and 28 Heads of Guidance and Counseling while Yamane (1967) formular was used to select 364 learners who were stratified according to their school populations. Questionnaires, Interview Schedules were used as research instruments. Halfsplit - half technique was used to testreliability of the instrumentsitems on the questionnaire to yield a Cronbach's alfa value of $r=0.85$. Quantitative data was presented in frequency counts. Regression analysis tested relationship at 0.05 precision level.The results showed that Pornography from You Tube influenced academic performance by 53.2\% ( $r=$ $.532, P=.038) ;$ Pornographic literature and pictures by $41.0 \%(r=.410, P=.003)$ while soap operas influence was $50.8 \%(r=.508, P=.001)$. The study concluded that the most influential Internet Pornography that affect academic achievements of secondary schools' students in Kakamega Central Sub-County are googled from YouTube followed by soap operas and Pornographic literature and pictures in that order. It was recommended that the government and parents be asked to participate in the efforts to block, prevent and advise learners on influences of sex related activities found online.

Keywords: Sex-related activities; academic performance, online pornography

\section{Introduction}

Sexual behavior associated with high risks among adolescents is a vital concern to guardians,teachers and health authorities worldwide. Statistics regarding teenage pregnancies are quite starling. Each year roughly $10 \%$ of school going children between ages 15-17 get pregnant and abort (Esere, 2008). Studies by Kreiter, Krowchuk, Charles, Woods, Sinal, (2009) found that there is a negative relationship between the age of a learner's first sex experience and his or her academic achievement. exposure of adolescents to sex activities vary from regions to regions. These variations have led to differentials in academic performances (Farrington, Sutton, \& Utting, 2006). Regions whose learners have limited exposure to media tend to have high achievements in schools. Sexually active teens are not only prone to dropping out of high school but also fail to complete college studies (Haibin Li (2009). Active participation inmass media and peer pressure are statistically negative significant predictors ofgood academic performance in adolescents. Research has found out that students exposed to both electronic and print media are more likely to engage in sex than those with low exposure to media (Jones, \& Espey, 2008).

\section{Literature Review}

This study employed the Psychosocial Personality by Erikson (1968) theory to postulate that development of an individual is the outcome of his interaction with the social environment to support its findings. There is a limitless range of content that is available on the Internet today other than previously considered media like music, You Tube, television, games, and videos. learners are able to view the pornographic content from their computers, video players as well as their phones and television sets, this new portability feature that is available on social media makes it possible for people to use 
the internet in a number of conceivable ways throughout the day. Adolescents are submerging themselves into the social networking sites. these sites have proved to play a major role in their lives. Most of the adolescents have engaged in viewing pornography in soap operas especially during the dead hours of the night.According to western culture there is a strong association between learners' behavior and their failure in academics (Kaiser Family Foundation. (2003). Scholars allege that the connection existing between behavior and academic achievement can be explained from two perspectives. The first point of view is the common-developmental-antecedent explanation. People with this perspective believe the link connecting the behavioral problems and academic achievement is associated by genetics, innermost factors or environmental antecedents (Dorius, Heaton and Steffen (2003).

Another view put across is the informal relation explanation. There are three models that are been approved to elaborate the informal link amid students' performance in school and their behavioral problems. The first plausible model is that under performance is an outcome of the internet related problematic behavior. Therefore, poor performance in school is a consequence of low less commitment in school activities and exasperation (Dwyer, 2003). Scholars opine that children spend more time on the media rather than engaging in learning activities that are academically oriented (Mensch, Clark, Lloyd. \& Erulkar, 2011). the frequency and diversity of sex experience for females is strongly associated with previous sex abuse. Girls that have education aspirations and are academic achievers tend to abstain from sex (Figlio, and Ludwig, (2000). For girls it is implied that the less time they spend studying the more they negatively associate success in education (Crockett ,2006; Whitebeak 2009). research has revealed that girls are likely prone to having sex and dropping output of school when they interact with pears using social media.

In Kenya, teenage pregnancy has emerged as a significant public health concern because of its contribution to increased fetal and maternal mortality, increased rate of sexually transmitted infections and declining socio-economic status of women. Several organizations have come up with programmes that help educate young people with information about a variety of issues although the programmes are scarce and only reach a small number of teens (McCarthy, \& Grodsky, 2010). While schools are not providing comprehensive information, students believe that their information needs should be met by the school. According to the Kenya's Ministry of Education (2015), statistics on academic performance in secondary schools dropped from $92.1 \%$ in 2012 to $89.6 \%$ in 2014.This drop is partly blamed on teenage pregnancies.

Kenya's pregnancy rates stand at about 20 percent for teenagers (Omotere, 2011). This is a concern to guardians, teachers, and health authorities as it promotes wastage in education system. Teenage pregnancy is a major social problem in Kakamega County, it was $19 \%$ in 2008. In Kakamega Central Sub-County, teenage pregnancy rates stand at about 30 percent of the students in school. It is hypothesized that at this rate of pregnancies in students, performance in national examination shall become dismal. The purpose of this research was to determine the relationship between sex-related activities and academic achievements of students in Kakamega Central Sub-county. it specifically sought to investigate the degree at which exposure to Internet Pornography had affected academic achievements of secondary school students in Kakamega Central Sub-County.

\section{Materials and Methods}

The researcher adopted an ex-post facto research design to collect both quantitative and the qualitative data. A total of 4073 respondents consisting of 28 principals, 28 Heads of Department Guidance and Counseling and 4017 students participated. she used purposive sampling to select 28 principals and 28 HoDs of G \& C. Yamane (1967) formular was used to find 364 learners. Questionnaires, Interview Schedules were used as research instruments. Split-half-Split technique was used to test reliability of the instruments that yielded $r=0.85$ a Cronbach's alfa value. Quantitative data was presented in frequency counts while regression analysis tested the effect of the independent on dependent variable at 0.05 precision level as advised byKombo, \&Tromp, (2006).

\section{Results and Discussions}

The variable under investigation in this study was internet Pornography from internet sources. The indicators used for internet Pornography were You Tube, Pornographic literature and pictures and Soap Operas. table 1 has the results of the survey. 


\begin{tabular}{|c|c|c|c|c|c|c|c|c|}
\hline \multirow{2}{*}{\multicolumn{2}{|c|}{$\begin{array}{l}\text { I like googling on internet } \\
\text { for sex related activities }\end{array}$}} & \multicolumn{2}{|c|}{ Often } & \multicolumn{2}{|c|}{ Rarely } & \multicolumn{2}{|c|}{ Never } & \multirow[b]{2}{*}{ Total } \\
\hline & & $\mathbf{N}$ & $\%$ & $\mathbf{N}$ & $\%$ & $\mathbf{N}$ & $\%$ & \\
\hline \multirow[t]{2}{*}{ Gender } & Boys & 100 & 61.0 & 62 & 39 & 2 & .01 & 164 \\
\hline & Girls & 150 & $80.6 \%$ & 36 & 19.4 & 0 & 0 & 186 \\
\hline \multicolumn{2}{|c|}{ Total } & 250 & $71.4 \%$ & 98 & $28 \%$ & 2 & .01 & 350 \\
\hline \multirow[t]{3}{*}{ Age } & $14-16$ & 9 & 3.8 & 100 & 20.0 & 00 & 00 & 109 \\
\hline & 17-19 & 200 & $84 \%$ & 38 & $16 \%$ & 00 & 00 & 238 \\
\hline & Above 20 & 3 & 100.0 & 00 & 00 & 00 & 00 & 3 \\
\hline \multicolumn{2}{|c|}{ Total } & 212 & 60.6 & 138 & 39.4 & 00 & 00 & 350 \\
\hline \multirow[t]{2}{*}{ Class } & Form 2 & 155 & 94.5 & 9 & 5.5 & 00 & 00 & 164 \\
\hline & Form 3 & 180 & 96.7 & 6 & 3.3 & 00 & 00 & 186 \\
\hline \multicolumn{2}{|c|}{ Total } & 335 & 95.7 & 15 & $4.3 \%$ & 00 & 00 & 350 \\
\hline
\end{tabular}

Table 1: Frequency of Googling for Sex Related Activities Source: Field Data, 2018

From the analysis, $100(61.0 \%)$ boys visit internet to google for pornography. Only 62 (39.0\%) rarely participate in this activity. This implies that out of the 164 boys selected, the majority100 $(61.0 \%)$ spent their valuable academic time on googling pornographic materials from the internet. This leaves the minority 62 (39.0\%) boys concentrating on academic exercises. This perhaps explains why majority of the male students record weak grades in their summative Kenya Certificate of Secondary Education examinations in form four. Similarly, 150 (80.6\%) girls visit internet in search of pornography. Only $36(19.4 \%)$ rarely participate in this activity. This implies that out of the 186 girls selected, the majority150 (80.6\%) spent their valuable academic time on googling pornographic materials from the internet. This leaves the minority 36 (19.4\%) girls concentrating on academic exercises. This could also be used to explain why majority of the female students record weak grades in their final KCSE examinations. Theseresults are in agreement with Myers, 2013 and Steinberg, (2011) who affirm that girls in adolescent stage try new roles and identities. They experiment with various sex and educational activities to understand who they can be. Lack of self-identification leads a confusion role and over-identification with clowns and villains resulting to impulsive behavior in taste and style and intolerance academics.

The analysis on googling for pornography according to age of learners showed that out of 50 students in this age bracket, majority $40(80.4 \%)$ adolescents google for pornography on the internet. 10\% rarely participate in this activity indicating that approximately $10 \%$ of the enrolled students in the age range of 14 to 16 years spent their time on academic exercises. The majority $40(80.4 \%)$ waste their valuable academic time on googling for pornographic materials. This implies that googling for pornographic literature on the internet affects academic performance

Again, out of 250 students in age bracket of $17-19$ years, the majority $200(80 \%)$ often google for pornography on the internet. $50(20 \%)$ rarely participate in this activity indicating that approximately $20 \%$ of the enrolled students in the age range of 17-19 years spent their time on academic exercises while the majority $80 \%$ waste their valuable academic time on pornographic venturis. This implies that learners in this age group experience identity crisis that distracts their attention on non-academic issues argues that this distractioninterferes with their academic progress (Sigmund Freud, 1970).

Analysis of results on googling for pornography according to the class in which the learners were enrolled in showed that out of 164 students in form two,155 (94.5\%) adolescents google for pornography on the internet. The remaining 5.5\% rarely participate in this activity. This implied that approximately 5.5\% of the enrolled students in form two classes in Kakamega Central Sub County Secondary Schools spent their time on academic exercises. The majority 94.5\% waste their valuable study time googling for pornography on internet. Out of 186 students in form three adolescents, 180 (96.7\%) adolescents google for pornography on the internet. The remaining 3.3\% rarely participate in this activity. This showed that approximately 3.3\% of the enrolled students in form three classes in the Sub County Secondary Schools spent time on academics whereas the majority $96.7 \%$ wastes their valuable study time in search of pornographic materials on the internet. These results agree with scholars such as Kerlinger, (2004) found out that there is a correlation between internet use and academic performance of learners.

In his study, Moon (2011) averred 'googling pornography on YouTube has a negative impact on students' achievements'. Nyamora, (2012) revealed that social network is mainly used by teens for making friends and chatting whereas National Educational Welfare Board (2008) claimed that internet addiction notably relates to students' academic achievements, as well as their personal attributes. Lloyd, Mensch, \&Clark, (2000) observes that today'syouths have become technology addicts and are quite introverted. The researcher opines that most learners in adolescent stage are mostly affected in their class work because they devote most of their valuable time googling for pornography. To test if there was a statistically significant connection that exists between exposure to internet pornography and the academic performance of form two and form three secondary schools' students in Kakamega Central Sub-County, the researcher used regression model to determine the extent (Often, Rarely and Never) to which Internet Pornography affect Academic Performance of form two and form three students. the results were recorded in Table 2 


\begin{tabular}{|c|c|c|c|c|c|c|}
\hline \multirow{2}{*}{\multicolumn{2}{|c|}{ Variable 1}} & \multicolumn{2}{|c|}{$\begin{array}{c}\text { Unstandardized } \\
\text { Coefficients }\end{array}$} & \multirow{2}{*}{$\begin{array}{c}\begin{array}{c}\text { Standardized } \\
\text { Coefficients }\end{array} \\
\text { Beta } \\
\end{array}$} & \multirow[t]{2}{*}{$\mathbf{t}$} & \multirow[t]{2}{*}{ Sig. } \\
\hline & & $\mathrm{B}$ & Std. Error & & & \\
\hline \multirow{4}{*}{$\begin{array}{c}\text { Internet } \\
\text { Pornography }\end{array}$} & Constant & 7.731 & 3.521 & & 3.557 & .000 \\
\hline & You Tube & .933 & .667 & .532 & .556 & .038 \\
\hline & $\begin{array}{l}\text { Pornographic } \\
\text { literature } \\
\text { \&pictures } \\
\end{array}$ & .766 & .502 & .410 & 1.851 & .003 \\
\hline & Soap Operas & .74 & .673 & .508 & .155 & .001 \\
\hline
\end{tabular}

Table 2: Internet Pornography and Academic Performance

a. Dependent Variable: Academic Performance of Students in Compulsory Subjects $P<0.05$

Results of the analysis in table 2 showed that the extent to which ponography from YouTube affected academic performance of form two and form three students in secondary schools in Kakamega Central Sub-County was 53.2\% $(r=$ $.532, P=.038$ ). Pornography read from Pornographic literature and Pornographic pictures watched affected academic performance of students by $41.0 \%(r=.410, P=.003)$. Pornography watched from Soap Operas affected academic performance of students by $50.8 \%(r=.508, P=.001)$. in General, this result implied that ponography searched from You Tube had the highest effect on academic performance of adolescents in forms three and two by $53.2 \%(r=.532, P=.038)$.

These results confirm the findings from studies of scholars such asAfenyadu, \& Goparaju (2003) who found out that social media negatively impacts progress of students. They argue that the more students google pornographic materials from social networks, the more they lose concentration on their academic works. In their submission, HODs guidance and counseling observed 'most of the young students use social network sites solely for socializing activities rather than for academic purpose'. Principals in their discussions with the researcher remarked 'the impact of social media on students' academic achievements is enormous, students dedicate more of their time googling for non-academic literature. This is so especially during their vacations'. They added that social network is mainly used by students for making friends and chatting'.

\section{Conclusions and Recommendations}

This study concluded that the most influential Internet Pornography that affect academic achievements of secondary schools' students in Kakamega Central Sub-County are googled from You Tube followed by soap operas; Pornographic literature and pictures in that order. the researcher recommended that the government and parents be roped in to participate in the efforts to block, prevent and advise learners on dangers and influences of sex related activities found online.

\section{Acknowledgements}

First and foremost, thanks to God for His continued elegance in all circumstances that has enabled me to come this far. I thank Mount Kenya University for the opportunity to pursue this course. I also convey my deepest appreciation to my supervisors; Dr. Moses PoiPoi and Dr Christopher Omusulafor their scholarly enlightenment and advice. I acknowledge the support of all my course lecturers for facilitating my course work. To my colleagues and classmates at Kakamega Muslim Secondary School for the support offered. I am grateful to my dear husband, Harry Esemere for caring of our children during my absence from home. Special thanks go to my family members as well as all respondents who contributed and supported me in giving their opinions and ideas in one way or the other for the success of this work but are not mentioned by name, may God bless you all.

\section{References}

i. Afenyadu, D \& Goparaju L, (2003). Adolescent sex and reproductive health behavior in Dodowa, Ghana, Washington, DC: Center for Development and Population Activities.

ii. Esere, M.O. (2008). Effect of sex education programme on at-risk sex behaviour of school-going adolescents in Ilorin, Nigeria. African Health Science. 8(2): 120-125.

iii. Esu, A.E.O. (1999). Sex education in Nigerian schools: Issues facing adolescents and Nigerian educators. In: Nwachukwu IDN, editor. Contemporary Issues in Nigerian Education and Development. Enugu: Sam Star \& Company; pp. 291-301.

iv. Farrington, D, Sutton, C. \& Utting, D. (2006). Nipping criminality in the bud. The Psychologist, Vol. 19, No. 8, 470479.

v. Figlio, D.N. and Ludwig, J. (2000): Sex, Drugs, and Catholic Schools: Private Schooling and Non-Market Adolescent Behaviors, National Bureau of Economic Research, Working Paper 7990.

vi. withMyers, (2013) and Steinberg, (2011) Self-esteem and adolescent sex behaviors, attitudes, and intentions: A systematic review. Journal of Adolescent Health.38:310-319.

vii. Haibin Li (2009).Is There a Correlation between Academic Achievement and Behavior in Mainland Chinese Students?Asian social science journal, vol. 5. No. 4

viii. Jones, N., \& Espey, J. (2008).Increasing visibility and promoting policy action to tackle sex exploitation in and around schools in Africa: A briefing paper witha focus on West Africa. Dakar: Plan West Africa.

ix. Kaiser Family Foundation. (2003). National survey of adolescents and young adults: sex health knowledge, attitudes and experiences. Retrieved 13/09/2014, from www.kff.org/youthhivstds/3218-index.cfm. 
x. Kerlinger, N. F. (2004). Foundations of Behavioral Research.2nd Edition. Surjeet Publication, Delhi.

xi. Kombo, D. \& Tromp, D. (2006). Proposal and thesis writing: An introduction. Kenya: Pauline's Publication Africa.

xii. Kreiter, S.R., Krowchuk, D.P., Charles R., Woods, C.R., Sinal, S.R. et al (2009). Gender Differences in Risk Behaviors Among Adolescents Who Experience Date Fighting. Journal American Academy of Pediatrics.

xiii. Lin, J.S., Whitlock, E., O'Connor, E., Bauer, V. (2008). Behavioral Counseling to Prevent Sexly Transmitted Infections: A Systematic Review for the U.S. Preventive Services Task Force Recommendation Statement. Annals of Internal Medicine. 149(7):491-496.

xiv. Lloyd, C.B., Mensch, B.S. \& Clark, W.H. (2000). The effects of primary school quality on school dropout among Kenyan girls and boys. Comparative Education Review 44(2):113-47.

xv. McCarthy, B. \& Grodsky, E. (2010) 'Sex and School: Adolescent Sex Intercourse and Education,' Presented at the 105th Annual Meeting of the American Sociological Association; Aug. 2010.

xvi. Mensch, B.S., Clark, W.H. Lloyd, C.B. \& Erulkar, A. (2011). Premarital Sex, and Schoolgirl Pregnancy and School Quality in Rural Kenya. Studies in Family Planning 32(4):285-301.

xvii. Ministry of Education (2009). Primary and Secondary Schools Enrolment. Government Printer, Nairobi.

xviii. National Educational Welfare Board (2008). Developing a Code of Behaviour: Guidelines for Schools. Retrieved on 11-04-2013 from www.newb.ie/downloads/pdf/guidelines_school_codes_eng.pdf

xix. Nyamora, J.N. (2012). Effects of Adolescent Sex-Related Activities on Academic performance Secondary School Students in Kenya. Unpublished Masters Thesis, MMUST.

xx. Omotere, T. (2011). The influence of peer group on adolescents' academic performance A case study of some selected schools in Ogun State. Ogun:Ego Booster Publishers 